\title{
Peranan Pusat Produksi Melon Hidroponik bagi Politeknik Negeri Lampung
}

\author{
Rizka Novi Sesanti $^{\# 1}$, Sismanto ${ }^{\# 2}$, Hilman Hidayat ${ }^{\# 3}$ \\ \#Program Studi Teknologi Produksi Tanaman Hortikultura Politeknik Negeri Lampung \\ Jl. Soekarno-Hatta No 10, Rajabasa Bandar Lampung \\ 1rizka@polinela.ac.id
}

\begin{abstract}
Pusat Produksi Melon Hidroponik di Politeknik Negeri Lampung dikembangkan melalui kegiatan Iptek bagi Kreativitas dan Inovasi Kampus (IbKIK), sebagai wahana dosen, teknisi, dan mahasiswa untuk mengimplementasikan ilmu dan keahliannya dalam rangka mendapatkan umpan balik dari masyarakat terutama dalam hal kewirausahaan, juga membantu pemenuhan kebutuhan buah melon dengan kualitas baik. Pusat Produksi Melon Hidroponik dilaksanakan selama tiga tahun. Tahun pertama target yang dicapai adalah pendirian Pusat Produksi Melon Hidroponik, peningkatan kapasitas dan produksi melalui pengembangan greenhouse, pemasaran, dan pelibatan mahasiswa melalui kegiatan praktikum dan proyek usaha mandiri (PUM) berbasis produksi melon. Pusat produksi melon hidroponik berperan sebagai tempat kegiatan produksi melon hidroponik, praktikum mahasiswa berbasis produksi, penelitian dosen dan mahasiswa, lokasi praktik kerja lapangan (PKL) siswa SMK Pertanian, kunjungan edukasi, dan pelatihan hidroponik. Keberadaan pusat produksi melon hidroponik dapat membantu dalam pengembangan teknologi hidroponik, membantu kegiatan akademik dosen dan mahasiswa, dan turut serta mengenalkan Politeknik Negeri Lampung ke masyarakat luas.
\end{abstract}

\section{Pendahuluan}

Melon merupakan salah satu komoditas buah di Indonesia yang memiliki prospek baik untuk dikembangkan, hal ini dibuktikan dari angka produksi Nasional untuk komoditas ini yang relatif terus meningkat. Pada tahun 2015 produksi melon sebesar 172.772 ton, angka produksi ini lebih tinggi jika dibandingkan dengan produksi tahun 2014 sebesar 150.347 ton dengan kenaikan sebesar 14,92\% (Kementerian Pertanian, 2016). Fenomena yang sama juga terlihat di tingkat provinsi, seperti Provinsi Lampung, produksi melon terus meningkat dari tahun 2011-2015, yaitu berturut-turut 89 ton, 742 ton, 832 ton, 876 ton, dan 1.363 ton (Kementerian Pertanian, 2016). Berdasarkan angka tersebut, diprediksi trend produksi melon di Provinsi Lampung untuk tahun- tahun ke depan masih terus meningkat, dan didukung dengan letak Provinsi Lampung yang strategis dekat dengan ibukota sehingga memudahkan untuk pemasaran dan transportasi.

Dari keseluruhan produksi melon di Provinsi Lampung semuanya menggunakan teknik budidaya konvensional dimana melon ditanam di lahan persawahan sebagai tanaman selang setelah pertanaman padi. Hal ini menyebabkan kualitas buah melon kurang baik dengan rasa tidak manis (brix dibawah 11) dan pasokan melon menjadi tidak berkesinambungan. Produksi melon di Provinsi Lampung meningkat pada musim kemarau atau pada musim gadu (saat sawah irigasi teknis tidak mendapatkan jatah air irigasi).

Politeknik Negeri Lampung merupakan satu-satunya institusi yang mengembangkan teknik budidaya melon menggunakan sistem hidroponik di Provinsi Lampung.
Sehingga pengembangan pusat produksi melon hidroponik yang dibangun tidak serta merta menyebabkan usaha produksi melon konvensional yang dilakukan petani menjadi terganggu. Produk yang dihasilkan dari budidaya melon dengan sistem hidroponik memiliki keunikan/keunggulan dari segi kualitas buah dan memiliki segmen pasar yang berbeda dibanding produk hasil budidaya melon dengan sistem konvensional.

Keunggulan produk melon hidroponik yang dikembangkan di Politeknik Negeri Lampung adalah benih yang digunakan untuk budidaya melon hidroponik menggunakan benih bersertifikat, unsur hara yang digunakan sebagai nutrisi tanaman melon hidroponik merupakan unsur hara khusus hidroponik $\mathrm{AB}$ Mix yang diracik sendiri (racikan Polinela), pemberian unsur hara ke tanaman terukur konsentrasi, volume dan waktu pemberiannya, sistem irigasi yang dipakai adalah sistem irigasi tetes (drip irrigation) dimana setiap tanaman mendapatkan 1 selang emitter untuk saluran larutan nutrisi, media tanam yang dipakai adalah arang sekam yang steril dan maksimal pemakaian hanya 1 tahun, pangsa pasar warga Politeknik Negeri Lampung dan masyarakat sekitar kampus dan direncanakan memasarkan ke hotel dan supermarket yang ada di Lampung, penggunaan pestisida dilakukan untuk sterilisasi greenhouse dan pada saat pertanaman dilakukan penggunaan pestisida menyesuaikan kondisi serangan dilapangan dengan menerapkan prinsip 5 T yaitu tepat sasaran, tepat jenis, tepat waktu, tepat dosis/konsentrasi, dan tepat cara penggunaan.

Dengan adanya kegiatan pengembangan pusat produksi melon hidroponik di Politeknik Negeri Lampung, maka sarana dan prasana penunjang kegiatan produksi melon, 
pelatihan, kunjungan edukasi, pelatihan dan penelitan semakin lengkap. Penelitian yang dilakukan dosen akan lebih banyak jumlah dan lebih baik kualitasnya sehingga kesempatan untuk memperoleh temuan HKI Perguruan Tinggi semakin terbuka lebar.

\section{A. Masalah}

Politeknik Negeri Lampung (Polinela) merupakan perguruan tinggi vokasi yang berada di Provinsi Lampung. Sebagai perguruan tinggi vokasi, maka otomatis persentase praktikum lebih banyak dibandingkan kuliah, hal ini menuntut tersedianya sarana dan prasarana yang memadai untuk kegiatan praktikum. Sampai dengan tahun 2016, Polinela hanya memiliki satu buah greenhouse hidroponik. Kegiatan yang dilakukan dalam greenhouse tersebut hanya terbatas praktikum mata kuliah Budidaya Sistem Hidroponik dan Irigasi Pertanian, sehingga keberadaan greenhouse tersebut kurang memiliki nilai kebermanfaatan. Untuk itu dilakukan kegiatan inovasi melalui pembuatan Pusat Produksi Melon Hidroponik yang dapat mengembangkan sarana dan prasaran hidroponik serta meningkatkan fungsi greenhouse dalam menunjang kegiatan akademik dan kewirausahaan (softskill) bagi dosen, mahasiswa, dan membantu masyarakat dalam mengenal sistem budidaya hidroponik.

\section{TARGET DAN LUARAN}

Target dan luaran dari kegitan ini adalah terbentuknya Pusat Produksi Melon Hidroponik di Politeknik Negeri Lampung, sehingga dapat berperan sebagai tempat produksi melon hidroponik (3-4 musim tanam/greenhouse/tahun), sebagai tempat praktikum mahasiswa berbasis kegiatan produksi, tempat proyek mahasiswa, tempat penelitian dosen dan mahasiswa, tempat kunjungan edukasi, dan tempat pelatihan edukasi.

\section{METODE PELAKSANAAN}

Kegiatan Iptek bagi Kreatifitas dan Inovasi Kampus (IbKIK) Pusat Produksi Melon Hidroponik ini dilaksanakan melalui beberapa tahap yaitu perencanaan kegiatan, pelaksanaan kegiatan dan evaluasi. Perencanaan kegiatan diawali dengan melakukan identifikasi kesiapan pelaksanaan kegiatan seperti kesiapan bahan baku produksi, kesiapan produksi melon, sarana prasarana kegiatan, manajemen, pemasaran, sumberdaya manusia, dan kebutuhan pendanaan kegiatan. Setelah semua data teridentifikasi dan siap untuk memulai kegiatan maka dibuat target capaian kegiatan yang terukur dan terjadwal, hal ini menjadi acuan dalam pelaksanaan kegiatan.

Pelaksanaan kegiatan dilakukan dengan mengacu pada target kegiatan. Kegiatan pertama yang dilakukan adalah pembentukan Pusat Produksi Melon Hidroponik. Setelah terbentuk Pusat Produksi melon, maka dilakukan kegiatan produksi melon secara terus menerus serta menambah kapasitas usaha dengan membangun 1 buah greenhouse lagi, sehingga pada tahun berikutnya target produksi bisa ditingkatkan hingga 2 kali lipat dari tahun sebelumnya. Proses produksi untuk menghasilkan kualitas melon yang baik dilakukan melalui tahapan budidaya yaitu persiapan greenhouse, persemaian dan penanaman, pemeliharaan, panen dan pascapanen, dan pemasaran.

Kegiatan selanjutnya adalah memfasilitasi dan melengkapi sarana dan prasarana di pusat produksi melon hidroponik, sehingga siap digunakan sebagai tempat kegiatan akademik, kegiatan kewirausahaan, kegiatan penelitian dosen dan mahasiswa, bahkan sebagai tempat kunjungan edukasi dan pelatihan hidroponik bagi masyarakat.

Evaluasi merupakan kegiatan mengkaji rangkaian pelaksanaan kegiatan secara keseluruhan serta mengindentifikasi kendala-kendala dalam pelaksanaan kegiatan. Evaluasi dilakukan oleh seluruh tim yang terlibat dalam kegiatan, dan hasil evaluasi dipakai untuk perbaikan rencana kegiatan di tahun berikutnya.

\section{IV.HASIL DAN PEMBAHASAN}

\section{A. Pusat Produksi Melon Hidroponik Sebagai Tempat Produksi Melon Hidroponik}

Produksi melon hidroponik dilakukan dengan cara memadukan antara pelaksanaan kegiatan akademik berupa praktik mahasiswa yang berorientasi produksi dengan kegiatan kewirausahaan yang dikelola oleh unit produksi melon hidroponik. Proses produksi untuk menghasilkan kualitas melon yang baik dilakukan melalui budidaya melon yang menerapkan teknologi hidroponik sistem irigasi tetes. Penerapan proses produksi yang benar akan menghasilkan buah melon yang memiliki penampilan menarik, disukai konsumen, bobot besar, harum, daging buah tebal, dan rasa yang manis (14-17 ${ }^{\circ}$ brix).

Prosedur produksi melon dengan sistem hidroponik meliputi sterilisasi greenhouse, persiapan media tanam, persiapan instalasi hidroponik dripp irigation, pembibitan, penanaman, pemeliharaan, dan panen. Sterilisasi greenhouse dilakukan dengan cara membersihkan dinding, dan lantai greenhouse dari kotoran, hama dan penyakit bekas pertanaman sebelumnya. Greenhouse disapu, disemprot air, dikeringkan, dan disemprot pestisida. Selain greenhouse media tanam berupa arang sekam dan pasir juga diaplikasi pestisida, hal ini dilakukan untuk mencegah perkembangbiakan hama dan penyakit di dalam media tanam akibat pertanaman sebelumnya. Setelah aplikasi pestisida greenhouse dibiarkan dalam kondisi tertutup selama kurang lebih satu minggu.

Satu minggu sebelum kegiatan sterilisisasi greenhouse, dilakukan kegiatan pembibitan tanaman melon. Benih melon disemai dalam plastik ukuran $6 \times 10 \mathrm{~cm}$ yang telah diisi media arang sekam. Bibit melon siap tanam pada umur 14 hari setelah semai, atau sudah muncul daun sejati. Penanaman bibit melon dilakukan dengan cara membuka plastik pada bibit dan di tanam pada polybag yang telah diisi arang sekam dan pasir (1:1), usahakan agar akar pada bibit 
tidak rusak. Penanaman dilakukan pada pagi atau sore hari, agar tanaman tidak layu. Setelah bibit ditanam, irigasi tetes (dripp irigation) dapat dijalankan. Masing-masing polybag akan mendapatkan 1 buah emiter yang mengalirkan nutrisi ke tanaman. Nutrisi diberikan ke tanaman sebanyak 8 kali setiap hari dengan durasi pemberian selama 3 menit, dengan selang waktu pemberian setiap satu jam sekali. Pemeliharaan tanaman melon meliputi pelilitan batang melon pada tali rambatan, pemangkasan tunas, pemupukan, pemberian pestisida, pemangkasan bunga jantan dan betina yang terletak dibawah daun 10 .

Buah melon yang dipelihara adalah buah yang muncul pada daun ke- 10 sampai 14. Hal ini dilakukan karena kondisi tanaman melon (jumlah daun dan diameter batang) sudah optimal dan dewasa, sehingga mampu menghasilkan buah yang berkualitas baik. Krestiani (1979), dalam penelitiannya menyatakan bahwa buah melon pada posisi daun kesebelas menunjukan bobot buah pertanaman, bobot buah perpetak, dan kadar gula tertinggi dibandingkan buah melon pada posisi daun ke tujuh dan ke sembilan.

Pemberian pestisida untuk tanaman melon di pusat produksi melon hidroponik dilakukan seminimal mungkin, dalam satu musim tanam pemberian pestisida (fungisida dan insektisida) ke tanaman maksimal hanya dilakukan sebanyak 3 kali, yaitu saat berumur 3 minggu setelah tanam, 5 minggu setelah tanam dan 8 minggu setelah tanam. Penggunaan pestisida di Pusat Produksi Melon Hidroponik Politeknik Negeri Lampung sangat jauh lebih sedikit dibandingkan dengan penggunaan pestisida untuk budidaya melon yang biasa ditanam petani (budidaya secara konvensional). Hartini dan Aswafi (2013), menjelaskan bahwa petani di Kabupaten Grobogan Jawa tengah menggunakan 4-7 jenis pestisida yang diaplikasikan $2-3$ hari sekali dengan dosis yang tidak sesuai takaran untuk budidaya tanaman melon.

Pusat Produksi Melon Hidroponik Politeknik Negeri Lampung menggunakan pembungkus buah untuk memastikan buah yang dipelihara tidak terserang hama dan penyakit. Buah melon mulai dibungkus setelah dilakukan seleksi buah (5 minggu setelah tanam). Selain dari pada itu, dipasang juga perangkap lalat buah pada 5-6 minggu setelah tanam dan 8-9 minggu setelah tanam. Perangkap lalat buah yang dipakai adalah perangkap lalat buah yang dibuat dari botol plastik air mineral ukuran 1,5 liter, yang diberi lubang pada bagian samping dan bagian dalam diberi kapas yang ditetesi $1-2 \mathrm{ml}$ metil eugenol. Menurut Mayasari (2018), metil eugenol sebanyak 1,5 ml yang diletakan pada perangkap lalat buah mampu mengendalikan lalat buah pada tanaman cabai.

Berlangsungnya kegiatan produksi di pusat produksi melon hidroponik akan membantu pemenuhan kebutuhan buah melon hidroponik yang berkualitas baik di masyarakat.
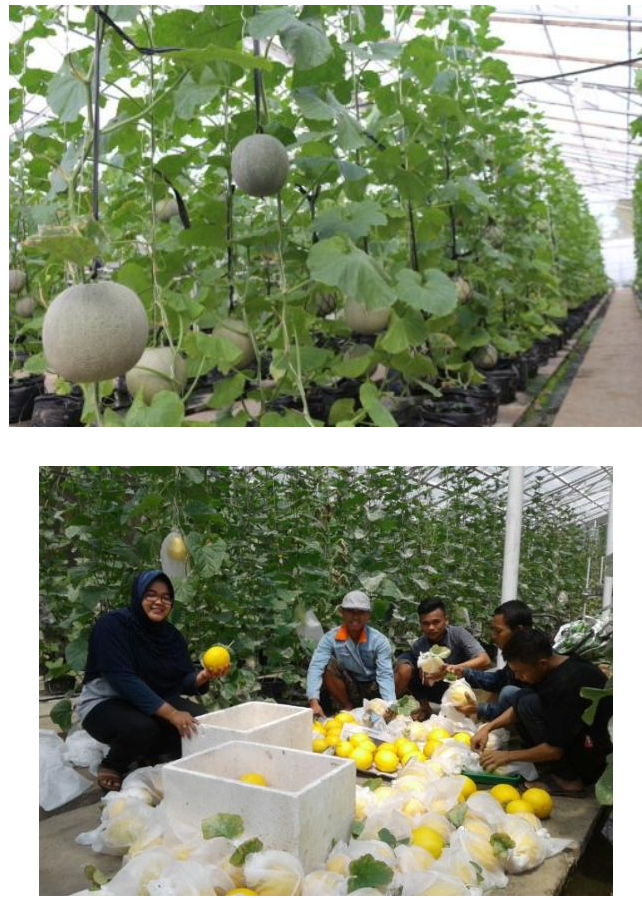

Gambar 1. Melon yang ditanam di Pusat produksi melon hidroponik

Produksi melon hidroponik dilakukan sebanyak 4 musim tanam per tahun pada greenhouse berukuran $300 \mathrm{~m}^{2}$. Jadwal tanam yang telah dilakukan Pusat Produksi Melon Hidroponik pada tahun 2017 adalah sebagai berikut:

TABEL 1. JADWAL TANAM MELON HIDROPONIK DI PUSAT PRODUKSI MELON HIDROPONIK POLITEKNIK NEGERI LAMPUNG

\begin{tabular}{|l|l|c|}
\hline \multicolumn{1}{|c|}{ Kegiatan } & \multicolumn{1}{|c|}{ Jadwal tanam } & \multicolumn{1}{c|}{$\begin{array}{c}\text { Hasil } \\
\text { Produksi (kg) }\end{array}$} \\
\hline \begin{tabular}{l} 
Produksi $\begin{array}{l}\text { Melon } \\
\text { Hidroponik }\end{array}$ \\
\cline { 2 - 3 }
\end{tabular} & $\begin{array}{l}\text { Musim 1 } \\
\text { (Januari-April 2017) }\end{array}$ & 836 \\
& $\begin{array}{l}\text { Musim 2 } \\
\text { (April_Juli 2017) }\end{array}$ & 594 \\
\cline { 2 - 3 } & $\begin{array}{l}\text { Musim 3 } \\
\text { (Agustus-20 Oktober } \\
\text { 2017) }\end{array}$ & 850 \\
\cline { 2 - 3 } & $\begin{array}{l}\text { Musim 4 } \\
\text { (Oktober 2017-Januari } \\
\text { 2018) }\end{array}$ & 860 \\
\cline { 2 - 3 } & $\begin{array}{l}\text { Musim 5 } \\
\text { (Januari 2018- Maret } \\
\text { 2018 }\end{array}$ & 891 \\
\cline { 2 - 3 } & $\begin{array}{l}\text { Musim 6 (2 greenhouse) } \\
\text { (Maret 2018-Juni } \\
\text { 2018) }\end{array}$ & 1761 \\
\hline
\end{tabular}




\section{B. Pusat Produksi Melon Hidroponik Sebagai Tempat Tempat Praktikum Mahasiswa}

Keberadaan pusat produksi melon hidroponik sangat membantu dalam kegiatan praktikum mahasiswa. Praktikum yang diterapkan pada pusat produksi melon adalah praktikum berbasis produksi. Konsep pola pembelajaran berbasis produksi adalah memberikan pengalaman pembuatan barang/memproduksi barang/model yang nyatanyata diperlukan dalam dunia industri atau masyarakat (Ardiansah, 2012). Hal ini sesuai dengan inti dari pendidikan vokasi yaitu mempersiapkan peserta didik memiliki keahlian terapan dalam bidang pekerjaan tertentu (Undang- Undang Republik Indonesia Nomor 20 tahun 2003). Dalam pelaksanaanya, mahasiswa ikut serta dalam seluruh rangkaian kegiatan produksi melon hidroponik, yang akan dijual ke konsumen. Jadwal kegiatan praktikum mahasiswa mengikuti jadwal produksi yang telah di tetapkan pusat produksi melon hidroponik. Walaupun mengikuti kegiatan produksi, mahasiswa tetap mendapatkan seluruh kompetensi yang dijanjikan pada kontrak perkuliahan.

Pusat produksi melon hidroponik menyediakan sarana dan prasarana lengkap untuk kegiatan praktikum mahasiswa pada berbagai mata kuliah, seperti budidaya sistem hidroponik, dan irigasi pertanian yang apabila dinilai dengan uang, maka pusat produksi melon hidroponik selain membantu berjalannya kegiatan praktikum, juga memberikan sumbangsih berupa materi kepada Politeknik Negeri Lampung.

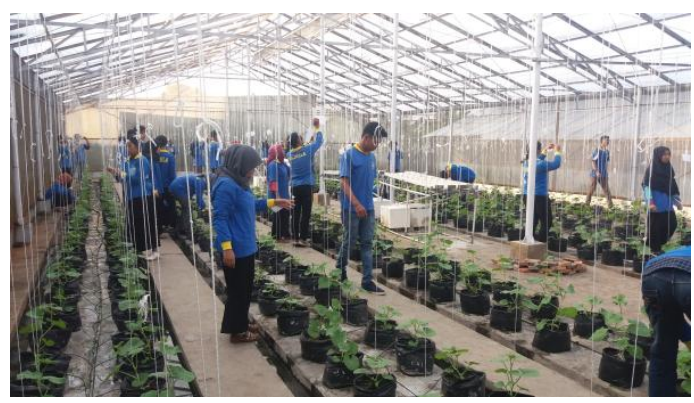

Gambar 2. Kegiatan praktik mahasiswa di pusat produksi melon hidroponik

Pusat produksi melon hidroponik juga menjadi sarana bagi mahasiswa dalam meningkatkan jiwa wirausaha dengan mengikuti aktivitas usaha berbasis kegiatan produksi di pusat produksi melon hidroponik. Hidayat, Herawati, Hidayati, \& Syahmaidi (2018), menambahkan bahwa pembelajaran kewirausahaan dengan pendekatan berbasis produksi adalah pembelajaran kewirausahaan yang berorientasi produk yang memiliki potensi komersil, dirancang dan disusun dalam pembentukan perencaan bisnis yang baik. Dengan mengikuti kegiatan di Pusat Produksi Melon hidroponik maka mahasiswa dapat belajar dan mendapatkan pengalaman usaha berbasis kegiatan produksi melon. Kegiatan kewirausahaan sangat penting dalam rangka membangun kemandirian mahasiswa sehingga dapat menghasilkan lulusan yang siap menciptakan lapangan pekerjaan (Wahyu dan Ranto, 2012).

\section{Pusat Produksi Melon Hidroponik Sebagai Tempat Penelitian Dosen dan Proyek Mahasiswa}

Pusat produksi melon hidroponik berperan sebagai tempat penelitian dan pelaksanaan proyek mahasiswa. Sehingga dosen dan mahasiswa dapat mengimplementasikan ilmu dan keahliannya dalam rangka mendapatkan umpan balik dari masyarakat, sehingga perguruan tinggi dapat mengembangkan ilmu pengetahuan dan teknologi (IPTEK) yang diperlukan masyarakat.

Kedepan Pusat produksi melon hidroponik dapat menjadi pusat kajian bagi pengembangan teknologi hidroponik terutama di Propinsi Lampung sehingga produk melon hidroponik di Lampung dapat meningkat, dapat menjadi cikal bakal munculnya industri hidroponik skala kecil dan menengah bertata kelola professional, dan dapat dimanfaatkan sebagai wahana unit pembelajaran bagi unit usaha lain, sehingga terjadi peningkatan kualitas SDM, yang akhirnya dapat meningkatkan nilai tambah suatu produk. Judul penelitian dosen dan proyek mandiri mahasiswa yang menggunakan sarana Pusat Produksi melon hidroponik disajikan pada Tabel 2 dan Tabel 3.

TABEL 2. DAFTAR NAMA DAN JUDUL PENELITIAN DOSEN

\begin{tabular}{|c|c|c|}
\hline No & Nama Dosen & \\
\hline 1. & $\begin{array}{l}\text { 1. Hilman } \\
\text { Hidayat } \\
\text { 2. Sismanto } \\
\text { 3. Rizka Novi } \\
\text { Sesanti }\end{array}$ & $\begin{array}{l}\text { Pengakaran Setek Jambu Air } \\
\text { Madu Deli Hijau Menggunakan } \\
\text { IBA Dan NAA Pada Sistem } \\
\text { Hidroponik } \\
\text { Technique Dan Konvensional Film }\end{array}$ \\
\hline 2 & $\begin{array}{l}\text { 1. Rizka Novi } \\
\text { Sesanti } \\
\text { 2. Sismanto } \\
\text { 3. Hilman } \\
\text { Hidayat }\end{array}$ & $\begin{array}{l}\text { Aplikasi Indole-3-Butyric Acid } \\
\text { Dan Naphthalene Acetic Acid } \\
\text { Pada Berbagai Bahan Setek Jambu } \\
\text { Madu Deli Hijau Dengan Sistem } \\
\text { Hidroponik } N f t\end{array}$ \\
\hline 3 & $\begin{array}{l}\text { 1. Rizka Novi } \\
\text { Sesanti } \\
\text { 2. Sismanto } \\
\text { 3. Hilman } \\
\text { Hidayat }\end{array}$ & $\begin{array}{l}\text { Peningkatan } \\
\text { Conductivity Larutan Nutrisi Dan } \\
\text { Jumlah Buah Per Tanaman } \\
\text { Terhadap Hasil Tanaman Melon } \\
\text { (Cucumis Melo L.) Dengan Sistem } \\
\text { Hidroponik }\end{array}$ \\
\hline
\end{tabular}

TABEL 3. DAFTAR NAMA DAN JUDUL PROYEK MAHASISWA

\begin{tabular}{|c|l|l|}
\hline No & \multicolumn{1}{|c|}{$\begin{array}{c}\text { Nama } \\
\text { Mahasiswa }\end{array}$} & \multicolumn{1}{|c|}{ Judul Proyek Mahasiswa } \\
\hline 1. & $\begin{array}{l}\text { Imbron } \\
\text { Febriyanto }\end{array}$ & $\begin{array}{l}\text { Usaha Melon Varietas Rio Dan } \\
\text { Erna Dengan Sistem Irigasi Tetes }\end{array}$ \\
\hline 2 & Desworo & $\begin{array}{l}\text { Produksi melon hidroponik } \\
\text { dengan penambahan } \mathrm{KNO}_{3}\end{array}$ \\
\hline 3 & Kridsada & Produksi melon hidroponik \\
\hline
\end{tabular}




\begin{tabular}{|c|l|l|}
\hline & & menggunakan pestisida nabati \\
\hline 4 & $\begin{array}{l}\text { Rohani } \\
\text { Veronica } \\
\text { Harianja }\end{array}$ & $\begin{array}{l}\text { Usaha } \\
\text { Hidroponik dengan Sistem Irigasi } \\
\text { Tetes }\end{array}$ \\
\hline 5 & $\begin{array}{l}\text { Rizky Norfatria } \\
\text { Ardy }\end{array}$ & $\begin{array}{l}\text { Usaha Melon Dengan Sistem } \\
\text { Hidroponik }\end{array}$ \\
\hline 6 & Eka Saputri & $\begin{array}{l}\text { Pengaruh Perbedaan Jumlah Buah } \\
\text { Terhadap Produksi Melon }\end{array}$ \\
\hline 7 & $\begin{array}{l}\text { Eva Damaiyanti } \\
\text { Esa } \\
\text { Krishalfi Dara } \\
\text { Vanja } \\
\text { Armayoga } \\
\text { Youricca } \\
\text { Pratiwi }\end{array}$ & $\begin{array}{l}\text { Ponia dengan sistem hidroponik } \\
\text { irigasi tetes }\end{array}$ \\
\hline 8 & $\begin{array}{l}\text { Heri Yani } \\
\text { Heni Safitri } \\
\text { Salman Abdur } \\
\text { Rafii } \\
\text { Robi Rosadi }\end{array}$ & $\begin{array}{l}\text { Peningkatan konsentrasi nutrisi } \\
\text { AB mix terhadap produksi melon } \\
\text { dengan sistem hidroponik }\end{array}$ \\
\hline
\end{tabular}

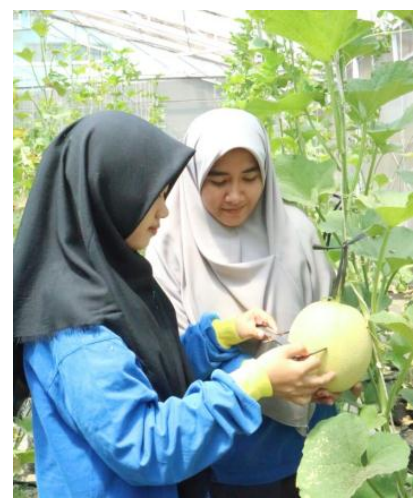

GAMBAR 3. PENGAMATAN BUAH MELON PADA PROYEK MAHASISWA

\section{Pusat Produksi Melon Hidroponik Sebagai Tempat Tempat Magang PKL siswa SMK}

Pusat produksi melon hidroponik menjadi tempat magang bagi siswa SMK Pertanian. Hal ini sangat dimungkinkan karena kegiatan produksi berjalan terusmenerus, siswa SMK dapat mengikuti kegiatan produksi melon secara utuh, dari mulai persiapan hingga pemasaran. Berdasarkan komunikasi dengan guru SMK pertanian di Lampung, pengetahuan dan keterampilan budidaya tanaman secara hidroponik hanya diberikan sebatas teori di SMK, hal ini disebabkan SMK tidak memiliki saran dan prasarana yang tidak memadai untuk melakukan praktik

Keberadaan pusat produksi melon hidroponik sangat membantu siswa SMK yang akan melakukan praktek kerja lapangan, karena pusat produksi melon hidroponik memenuhi syarat sebagai lokasi PKL. Selain mendapatkan ilmu pengatahuan, siswa SMK juga dapat melakukan aktivitas langsung dalam mengelola usaha melon hidroponik. Materi kegiatan yang didapat dari kegiatan PKL di Pusat produksi melon hidroponik adalah budidaya tanaman melon dengan sistem hidroponik dan pemasaran produk. Asal sekolah dan jumlah siswa yang magang di Pusat Produksi Melon Hidroponik disajikan pada Tabel berikut:

TABEL 4. ASAL SEKOLAH DAN JUMLAH MAHASISWA PKL

\begin{tabular}{|l|l|c|c|}
\hline No & Asal Sekolah & $\begin{array}{l}\text { Jumlah } \\
\text { Mahasiswa }\end{array}$ & Tahun \\
\hline 1. & $\begin{array}{l}\text { SMK Pertanian } \\
\text { Rawajitu Selatan }\end{array}$ & orang & 2017 \\
\hline 2. & $\begin{array}{l}\text { SMK Pertanian Tulang } \\
\text { Bawang }\end{array}$ & 1 orang & 2017 \\
\hline 3. & $\begin{array}{l}\text { SMK Pertanian } \\
\text { Rawajitu Selatan }\end{array}$ & orang & 2018 \\
\hline
\end{tabular}

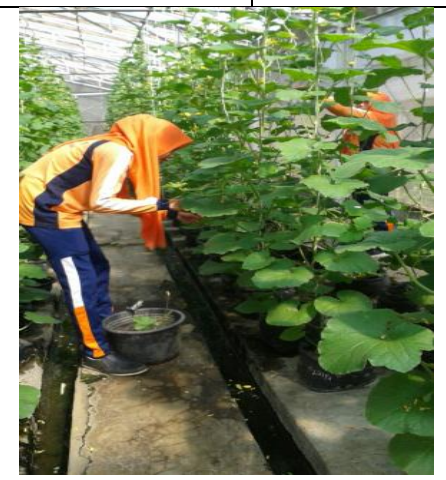

Gambar 4. Siswi SMK pertanian rawajitu Selatan yang PKL di pusat produksi melon hidroponik

\section{E. Pusat Produksi Melon Hidroponik Sebagai Tempat Kunjungan Edukasi}

Adanya pusat produksi melon hidroponik, dapat menjadi sasaran lokasi kunjungan edukasi siswa mulai dari TK hingga SMA atau umum. Hal ini dilakukan dengan membuka greenhouse untuk kunjungan dan wisata petik melon. Pusat produksi melon hidroponik menjadi wahana bagi masyarakat mendapatkan informasi dan teknologi tentang hidroponik dan pemanfaatan hasil riset dosen sehingga menjadi teknologi tepat guna aplikatif.

Banyaknya kunjungan masyarakat ke pusat produksi melon hidroponik dapat menjadi tolak ukur pengakuan masyarakat terhadap teknologi yang ditawarkan perguruan tinggi. Hal ini adalah feedback nyata dari masyarakat terhadap perguruan tinggi. Dalam setahun belakangan ini pusat produksi melon hidroponik telah dikunjungi oleh sekolah-sekolah dan perguruan tinggi. Daftar sekolah dan perguruan tinggi yang berkunjung ke Pusat Produksi Melon Hidroponik disajikan pada Tabel 4. 
TABel 4. Daftar PEngunjung Pusat Produksi Melon HidroponiK

\begin{tabular}{|c|c|c|c|}
\hline No. & Tanggal & Nama Sekolah & $\begin{array}{c}\text { Jumlah } \\
\text { pengunjung }\end{array}$ \\
\hline \multirow[t]{2}{*}{1} & 14 Juli 2017 & $\begin{array}{l}\text { SD Negeri Cahaya } \\
\text { Madani Pringsewu }\end{array}$ & 50 \\
\hline & $\begin{array}{l}10 \text { Agustus } \\
2017\end{array}$ & SDN 1 Rajabasa & 50 \\
\hline 2 & $\begin{array}{l}22 \\
\text { September } \\
2017\end{array}$ & STTP Bogor & 5 \\
\hline 3 & $\begin{array}{l}29 \\
\text { September } \\
2017\end{array}$ & $\begin{array}{l}\text { SMP Kristen } \\
\text { Penabur }\end{array}$ & 66 \\
\hline 4 & $\begin{array}{l}19 \text { Oktober } \\
2017\end{array}$ & $\begin{array}{l}\text { SD Kristen } \\
\text { Penabur }\end{array}$ & 135 \\
\hline 5 & $\begin{array}{l}13 \\
\text { November } \\
2017 \\
\end{array}$ & $\begin{array}{l}\text { TK Imannuel } \\
\text { Bandar Lampung }\end{array}$ & 44 \\
\hline 6 & $\begin{array}{l}30 \\
\text { November } \\
2017\end{array}$ & $\begin{array}{l}\text { TK Aisyiyah } \\
\text { Bandar Lampung }\end{array}$ & 50 \\
\hline 7 & $\begin{array}{l}\text { 6 Desember } \\
2017\end{array}$ & $\begin{array}{l}\text { Karang Taruna } \\
\text { Tanjung Bintang }\end{array}$ & 5 \\
\hline 8 & $\begin{array}{l}28 \\
\text { Desember } \\
2017\end{array}$ & STPP Magelang & 25 \\
\hline 9 & $\begin{array}{l}\text { 31 Januari } \\
2018\end{array}$ & TK Nurul Amal & 19 \\
\hline 10 & $\begin{array}{l}6 \text { Februari } \\
2018\end{array}$ & $\begin{array}{l}\text { SD Tunas Mekar } \\
\text { Indah }\end{array}$ & 5 \\
\hline 11 & $\begin{array}{l}9 \text { Februari } \\
2018\end{array}$ & $\begin{array}{l}\text { TK Yustikarini } \\
\text { Kemiling }\end{array}$ & 18 \\
\hline 12 & $\begin{array}{l}15 \text { Februari } \\
2018\end{array}$ & TK Pratama Kind's & 36 \\
\hline 13 & $\begin{array}{l}27 \text { Februari } \\
2018\end{array}$ & $\begin{array}{l}\text { TK IKAL Bandar } \\
\text { Lampung }\end{array}$ & 52 \\
\hline 14 & $\begin{array}{l}\text { 21 Maret } \\
2018\end{array}$ & $\begin{array}{l}\text { MA Mathlaul } \\
\text { Anwar Gisting }\end{array}$ & 22 \\
\hline 15 & $\begin{array}{l}22 \text { Maret } \\
2018\end{array}$ & $\begin{array}{l}\text { SD IT } \\
\text { Muhammadiyah } \\
\text { Gunter }\end{array}$ & 105 \\
\hline 16 & $\begin{array}{l}23 \text { Maret } \\
2018\end{array}$ & TK Al-Akbar & 60 \\
\hline
\end{tabular}

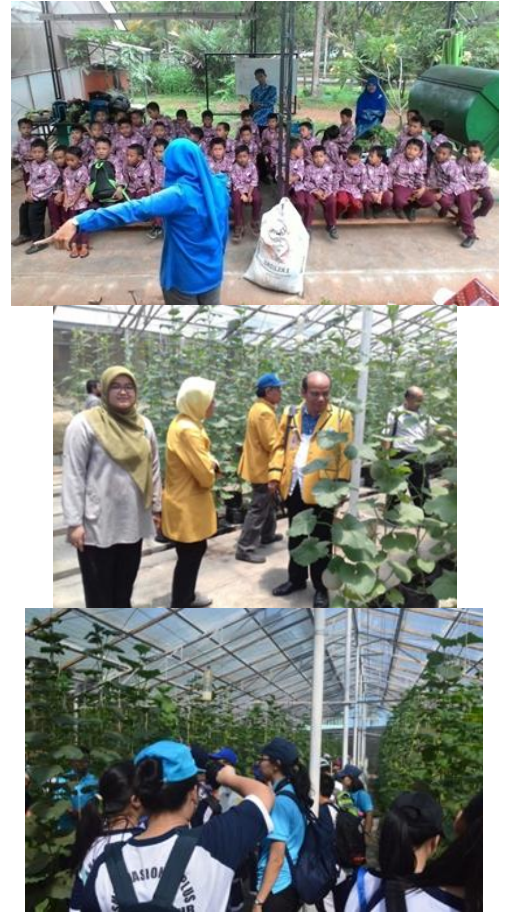

Gambar 5. Kunjungan masyarakat di pusat produksi melon hidroponik

F. Pusat Produksi Melon Hidroponik Sebagai Tempat Pelatihan Hidroponik

Perguruan Tinggi merupakan tempat bagi masyarakat untuk mendapatkan ilmu pengetahuan. Minat masyarakat yang tinggi tentang hidroponik khususnya di daerah perkotaan mendorong kegiatan pelatihan. Untuk itu pusat produksi hidroponik di Politeknik Negeri Lampung mengambil bagian dalam kegiatan pelatihan untuk masyarakat yang berminat melakukan budidaya tanaman dengan sistem hidroponik.

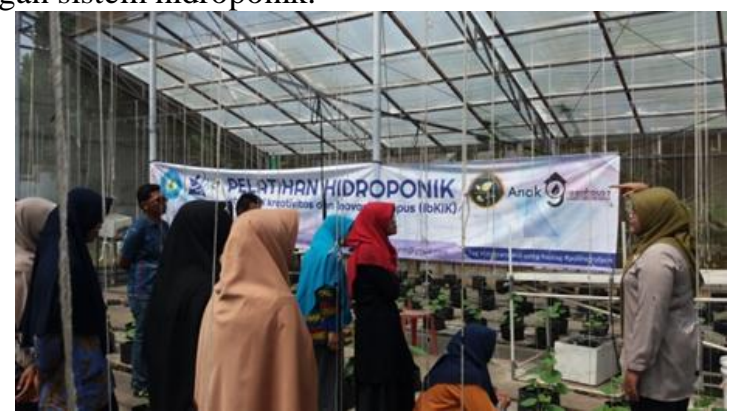

Gambar 6. Pelatihan hidroponik di Pusat produksi melon hidroponik 


\section{KESIMPULAN}

Pusat produksi melon hidroponik berperan penting dalam memajukan kampus Politeknik Negri Lampung. Pusat produksi melon hidroponik membantu memenuhi kebutuhan buah melon bagi masyarakat, menjadi wahana bagi mahasiswa, dosen, masyarakat dan mengembangkan ilmu pengetahuan di bidang hidroponik dan melakukan aktivitas berwirausaha.

\section{PENGHARGAan}

Penulis mengucapkan terima kasih kepada Direktorat Jendral Pendidikan Tinggi Indonesia yang telah membiayai Pengabdian Kepada Masyarakat ini melalui program Iptek Bagi Kreativitas dan Inovasi Kampus.

\section{DAFTAR PUSTAKA}

[1] Ardiansah. 2012. Analisis Kesiapan Sumber Daya Program Studi Dalam Pengelolaam Pola Pembelajaran Berbasis Produksi (Production based Education) Studi Pada Program Studi D3 Akuntansi Politeknik Negeri Semarang (POLINES). Jurnal Informasi Perpajakan, Akuntansi Dan Keuangan Publik, Vol 7(1), 07-09.

[2] Hartini, E., \& Aswafi, S. 2013. Kontaminasi Residu Pestisida Dalam Buah Melon di Kabupaten Grobogan. Laporan Akhir Penelitian Dosen Pemula. Universitas Dian Nuswantoro. Semarang.

[3] Hidayat, H., Herawati, S., Hidayati, A., \& Syahmaidi, E. 2018. Pembelajaran kewirausahaan dengan pendekatan berbasis produksi sebagai alternatif mempersiapkan lulusan berkualitas di pendidikan tinggi. In Seminar Nasional Pakar ke 1 (123-129). Lembaga Penelitian Universitas Trisakti. Jakarta

[4] Kementerian Pertanian. 2016. Laporan Kinerja Direktorat Jenderal Hortikultura Tahun Anggaran 2015. Laporan Kinerja. Kementerian Pertanian. Jakarta.

[5] Krestiani, V. (2009). Kajian Pemulsaan dan Letak Duduk Buah terhadap Hasil Melon ( Cucumis sativus L . ). Jurnal Sains dan Teknologi, Vol 2 (1), 1-7.

[6] Mayasari, I. (2018). Efektifitas Metil Eugenol terhadap Penangkapan Lalat Buah (Diptera: Tephritidate) pada Pertanaman Cabai (Capsicum Annuum L.) di Kabupaten Tanggamus. Skripsi. Universitas Lampung, Bandar Lampung.

[7] Undang-Undang Republik Indonesia No 20 Tahun 2003 Tentang Sisitem Pendidikan Nasional

[8] Wahyu, D., \& Ranto, P. (2012). Peranan Kampus Dalam Membangun Kemandirian. Jurnal Bisnis Manajemen Dan Akuntansi, Vol I (1), 65-73. 